Zabytkoznawstwo i Konserwatorstwo XLIII, Toruń 2012

Magdalena Iwanicka*, Katarzyna A. Cybulska*, Marcin Sylwestrzak** *Instytut Zabytkoznawstwa i Konserwatorstwa UMK, ${ }^{* *}$ Instytut Fizyki UMK

\title{
Nieinwazyjne badania in situ wybranych obrazów z kolekcji malarstwa i pasteli autorstwa Meli Muter za pomocą tomografii optycznej OCT
}

$\mathrm{M}$ uzeum Uniwersyteckie w Toruniu, które wspiera i prowadzi szeroko zakrojone badania naukowe nad sztuka polska, pozyskało do swoich zbiorów bardzo cenną kolekcję malarstwa i rysunku Meli Muter, wybitnej polskiej artystki ${ }^{1}$.

Mela Muter, artystka znana i ceniona w XX w., jest jedną z wielkich postaci kobiecych polskiego i światowego malarstwa. Wyjątkowe miejsce w jej dorobku zajmowała tematyka związana z macierzyństwem, a także ukazywanie biedy, szczególnie dramatyczne, jeśli bohaterami obrazów były dzieci i starzy ludzie. Muter malowała także sceny rodzajowe, martwe natury oraz pejzaże. W ciagu całego swojego życia Mela Muter czerpała z różnych nurtów i kierunków w sztuce, wypracowując swój własny niepowtarzalny styl, w którym można odnaleźć szerokie inspiracje malarstwem zarówno drugiej połowy XIX w., jak i zdobyczami malarstwa XX wieczne-

1 Wszystkie wymienione w niniejszym artykule przykłady obrazów autorstwa Meli Muter należą do prywatnej kolekcji Liny i Bolesława Nawrockich, obecnie zdeponowanej w Muzeum Uniwersyteckim w Toruniu; K. A. Cybulska, Historia kolekciji - Mela Muter w zbiorach Bolestawa i Liny Nawrockich [w:] Mela Muter. Malarstwo, red. M. A. Supruniuk, Katalog zbiorów Muzeum Uniwersyteckiego w Toruniu, t. 1, Toruń 2010, s. 41-46. 
go $^{2}$. Jej dorobek malarski obejmuje różne techniki, akwarele, rysunek, grafikę, ale przede wszystkim obrazy olejne, wykonywane na płótnie, tekturze, papierze i sklejce ${ }^{3}$.

W przypadku kilku dzieł autorstwa Meli Muter zdecydowano się na przeprowadzenie nieinwazyjnych badań in situ koherencyjną tomografia optyczną (OCT) ${ }^{4}$. Za badaniem obrazów w Muzeum przemawiała duża liczba obiektów, w tym kilka o sporych rozmiarach oraz fakt, że obrazy stanowiące depozyt nie moga być przewożone bez zgody właściciela.

Koherencyjna tomografia optyczna (OCT) pozwala na otrzymywanie w sposób nieinwazyjny i bezkontaktowy przekrojów budowy stratygraficznej dzieł sztuki w zakresie warstw przejrzystych i półprzejrzystych dla bliskiej podczerwieni z mikrometrową rozdzielczością. Technika wykorzystuje światło z zakresu bliskiej podczerwieni o małym natężeniu (około jednego miliwata), jest więc całkowicie nieszkodliwa dla obiektów zabytkowych ${ }^{5}$. Ze względu na łatwość transportu, szybkie pozyskiwanie i obróbkę danych oraz brak konieczności przygotowania obiektów do badania, system dobrze

2 B. Brus-Malinowska, O malarstwie Meli Muter, [w:] Muter (1876-1967). Kolekecja Bolestawa i Liny Nawrockich, kat. wyst., Muzeum Narodowe w Warszawie, grudzień 1994-luty 1995, oprac. B. Brus-Malinowska, B. Nawrocki, Warszawa 1994, s. 24-28.

3 Na temat twórczości Meli Muter oraz rozpoznania i określenia jej warsztatu malarskiego prowadzone sa w ramach dysertacji doktorskiej pt.: Warsztat malarski Marii Melanii Mutermilch - Meli Muter (1876-1967), artystki École de Paris, na podstawie obrąón olejnych z. kolekciji Bolestawa $i$ Liny Nawrockich, szeroko zakrojone interdyscyplinarne badania mgr Katarzyny A. Cybulskiej pod kierunkiem prof. UMK, dr hab. Justyny Olszewskiej-Świetlik, w Zakładzie Technologii i Technik Malarskich, Instytut Zabytkoznawstwa i Konserwatorstwa UMK.

${ }^{4} \mathrm{Na}$ temat praktycznego zastosowania OCT do celów badań i konserwacji malarstwa powstaje praca doktorska mgr Magdaleny Iwanickiej pt. Zastosowanie metody tomografii optycznej (OCT) w bęinwazyjnych badaniach struktury obrazón sə̨talugonych pod kierunkiem prof. Bogumiły J. Rouby, w Zakładzie Konserwacji Malarstwa i Rzeźby Polichromowanej, Instytut Zabytkoznawstwa i Konserwatorstwa UMK.

5 Przegląd zastosowań OCT do badania dzieł sztuki znaleźć można m.in. w pracach: P. Targowski, M. Iwanicka, Optical Coherence Tomography for structural examination of cultural heritage objects and monitoring of restoration processes - a review, Applied Physics A 106(2), Special Issue on Optical Technologies in Art and Archaeology DOI: 10.1007/s00339-011-6687-3, 265-277 (2011); P. Targowski, B. J. Rouba, P. Karaszkiewicz, M. Iwanicka, L. TymińskaWidmer, T. Łękawa-Wysłouch, E. A. Kwiatkowska, M. Sylwestrzak, Optyczna Koherentna Tomografia OCT - nowe narzedzie do dziatan konserwatorskich $i$ inwentaryzacyjnych, Wiadomości konserwatorskie 26, s. 94-107 (2009). 
nadaje się do częściowego i wstępnego rozpoznania budowy i stanu zachowania eksponatów w kolekcjach muzealnych.

\section{Problematyka konserwatorska i cel badań}

Jako że większość obiektów została nabyta przez Bolesława Nawrockiego bezpośrednio od artystki, lub zaraz po jej śmierci z wiarygodnych źródeł, ich autentyczność nie jest przedmiotem kontrowersji. Z uwagi na losy wielu z omawianych dzieł, ich zły stan zachowania przed nabyciem przez właściciela, większość obrazów była w przeszłości konserwowana, a zabiegi nie zostały wystarczająco udokumentowane. Część ingerencji w strukturę obiektów jest dziełem samej artystki, która w ostatnim okresie życia zdecydowała się na wprowadzanie w niektóre obrazy zmian, niekiedy wręcz gruntowne przemalowanie, jak też późniejsze sygnowanie swych wcześniejszych prac $^{6}$. Stąd też z kolekcją związana jest specyficzna problematyka konserwatorska.

Celem badań in situ koherencyjną tomografią optyczną (OCT) było rozpoznanie i uściślenie problemów konserwatorskich dotyczących większej grupy obrazów, jak również wytypowanie poszczególnych dzieł i obszarów do dalszych badań z użyciem innych nieinwazyjnych technik analitycznych. W szczególności, badania OCT miały na celu uzupełnienie informacji na temat występowania werniksów ${ }^{7}$, ocenę dawnych kitów oraz doprecyzowanie danych związanych z dwiema dość nietypowymi sygnaturami. W przypadku grupy obrazów w technice pastelu skupiono się na zagadnieniach z dziedziny profilaktyki konserwatorskiej. Do analiz wytypowano dziewięć

6 B. Nawrocki, Mela Muter - garś́ wspomnień, [w:] Mela Muter. Kolekcja Bolestawa i Liny Nawrockich, kat. wyst., Muzeum Narodowe w Warszawie, grudzień 1994-luty 1995, oprac. B. Brus-Malinowska, B. Nawrocki, Warszawa 1994, s. 7-8; J. Olszewska-Świetlik, K. A. Cybulska, Konserwvator wobec autorskich zmian $w$ driełach sztuki - zagadnienia etyczne $i$ estetyczne na prsykładzie twórczości Meli Muter, [tekst złożony do druku], Materiały pokonferencyjne: Wokót zagadnień estetyki zabytku po konserwacji i restauracji, konferencja naukowa Torun, 26-27 maja 2010 r.

$7 \mathrm{Na}$ podstawie dotychczasowych badań ustalono, że artystka nie stosowała świadomie werniksów. Jeśli takowe występuja, pochodzą zazwyczaj z przeprowadzonych zabiegów konserwatorskich. 
obrazów olejnych i dwa pastele z kolekcji liczącej siedemdziesiąt jeden przedstawień olejnych i cztery pastel

\section{Koherencyjna tomografia optyczna}

Istotą działania tomografii optycznej jest przetworzenie informacji o nieciagłościach podpowierzchniowej budowy obiektu na dwuwymiarowy obraz przekroju stratygraficznego, przypominający klasyczną fotografię mikroskopowa przekroju próbki materii zabytkowej. Poprzez skanowanie powierzchni linia obok linii uzyskać możemy dodatkowo trójwymiarowy model budowy wewnętrznej dzieła sztuki.

Technika OCT wykorzystuje zjawisko interferencji światła białego. W uproszczeniu można powiedzieć, że system zbudowany jest w oparciu o interferometr Michelsona, w którym badany obiekt ustawiony jest na końcu jednego ramienia a zwierciadło referencyjne na końcu drugiego. Promieniowanie sondujące ze źródła dzielone jest pomiędzy ramiona interferometru. Część rozchodząca się w ramieniu obiektowym wnika w strukturę badanego przedmiotu na głębokość uwarunkowana jego właściwościami absorpcyjnymi. Informacja o położeniu centrów rozpraszajacych (takich jak np. granice warstw, cząstki brudu czy ziarna pigmentów) w strukturze obiektu uzyskiwana jest poprzez analizę sygnału interferencyjnego uzyskiwanego w wyniku nałożenia promieniowania powracającego z obiektu z odbitym od zwierciadła referencyjnego. W używanej przez nasz Zespół odmianie spektralnej techniki OCT do analizy tej stosuje się szybką transformatę Fouriera.

W badaniach użyto mobilnego tomografu OCT skonstruowanego przez zespół fizyków z UMK specjalnie do zastosowań konserwatorskich (Il. 1$)^{8}$. Badany obiekt penetrowany jest przez światło o długościach fali z przedziału od 790 do $895 \mathrm{~nm}$. Rozdzielczość osiowa (zdolność do obrazowania warstwy o danej grubości) wynosi $4.5 \mu \mathrm{m}$ w powietrzu, (około

8 Prace nad konstrukcja tomografu OCT do badania obiektów zabytkowych prowadzone sa przez zespół w składzie: prof. dr hab. Piotr Targowski, dr Anna Szkulmowska, mgr Ewa A. Kaszewska, mgr inż. Marcin Sylwestrzak, mgr inż. Lukasz Ćwikliński. 
$3.0 \mu \mathrm{m}$ w werniksach i spoiwach malarskich), a rozdzielczość poprzeczna około $30 \mu \mathrm{m}$. Czas potrzebny do uzyskania pojedynczego przekroju dwuwymiarowego wynosi od 0,1 do 0,2 s. Instrument jest przystosowany do łatwego demontażu na elementy możliwe do transportu samochodem osobowym. Dzięki zastosowaniu techniki światłowodowej nie wymaga skomplikowanego strojenia po montażu w miejscu prowadzenia badań.

Dzięki temu, że technika jest szybka, nieinwazyjna i bezkontaktowa, może być stosowana wielokrotnie i w wielu miejscach obiektu. Ograniczenia dla badania nie stanowi rodzaj podobrazia: warstwy przypowierzchniowe obiektów wykonanych na podłożach całkowicie nieprzeziernych dla podczerwieni (drewno, metal itp.) moga być obrazowane za pomocą OCT, ponieważ badanie odbywa się z użyciem światła rozproszonego wstecz.

Interpretacja tomogramów nie nastręcza dużych trudności. W przypadku wszystkich tomogramów przedstawionych w tej pracy, światło pada od góry przez warstwę powietrza, natomiast kolory w tzw. fałszywej skali koduja intensywność rozproszonego światła. Na granicy powietrze - powierzchnia obiektu ta intensywność jest zazwyczaj największa z powodu dużej różnicy współczynnika załamania światła, czemu odpowiada kolor żółtoczerwony. Warstwy nierozpraszające światła, a przepuszczające je w głąb (jak powietrze lub werniksy) widoczne są na tomogramach jako czarne. Granice warstw oraz warstwy malarskie częściowo rozpraszające światło widoczne sa jako niebieskozielone. Struktury leżące poniżej nieprzeziernej dla promieniowania sondującego warstwy malarskiej są również widoczne w kolorze czarnym.

Ze względu na fakt, że długość skanów OCT wynosi zazwyczaj od 3 do $15 \mathrm{~mm}$, a grubość obrazowanej warstwy nie przekracza 0,5 $\mathrm{mm}$, większość tomogramów dla uczytelnienia przedstawia się w taki sposób, że skale pionowa i pozioma nie są sobie równe, a obraz rozciagnięty jest w kierunku pionowym.

W badaniach obrazów sztalugowych tomografia optyczna pomaga zazwyczaj stwierdzić, ile warstw werniksu leży na powierzchni i jaka jest ich grubość. W przypadku dzieł malarstwa wykonanych w technice warstwowej dobrze obrazowane są również laserunki z barwników organicznych i warstwy malarskie wykonane z użyciem pewnych pigmentów (jak np. smalta, 
ultramaryna, umbra palona). Warstwy wykonane z dodatkiem bieli zazwyczaj nie sa dostępne dla obrazowania OCT'

\section{Rezultaty badań}

Badaniom OCT poddano dziewięć obrazów olejnych na różnych podłożach (tektura, sklejka, płótno) oraz dwa pastele. Każdy z obrazów badano w wielu miejscach, w niniejszej pracy przedstawione zostaną więc jedynie wyniki przykładowe.

Większość obrazów olejnych w kolekcji została wykonana w technice nowoczesnej, alla prima, z użyciem kryjących farb wykazujących dużą absorpcje promieniowania podczerwonego. W związku z tym nie spodziewano się, ażeby tomografia optyczna mogła w znaczacym stopniu przyczynić się do poznania budowy technicznej warstw oryginalnych. Okazało się to jednak możliwe w przypadku obrazu olejnego na tekturze Portret Leopolda Staffa (il. 2a), który jest jednym z wcześniejszych dzieł Meli Muter, namalowanym w konwencji symbolizmu i w technice malarskiej zakorzenionej jeszcze w XIX wieku ${ }^{10}$. Badania OCT (il. 2c, d) ujawniły obecność dwóch cienkich warstw werniksu oraz, w ciemnych partiach, przejrzystej dla podczerwieni warstwy malarskiej ${ }^{11}$. Poniżej znajduje się warstwa widoczna na

9 M. Szkulmowski, M. Góra, M. Targowska, B. Rouba, D. Stifter, E. Breuer, P. Targowski, Zastosowanie tomografii optycznej do badania stratygrafii obrazów olejnych, [w:] Techniki analityczne w konserwacji zabytków, red. G. Śliwiński, Wydawnictwo Instytutu Maszyn Przepływowych, Gdańsk 2007, s. 79-83.

10 O obrazie obszernie piszą: E. Bobrowska-Jakubowska, Portret „szalonych lat”: Mela Muter na międzynarodowej scenie artystycznej Paryża, [w:] Mela Muter. Malarstwo, red. M. A. Supruniuk, (Katalog zbiorów Muzeum Uniwersyteckiego w Toruniu), t. 1, Toruń 2010, s. 17; K. Nowakowska-Sito, L'Inconnue de la Seine i jej wizerunki w satuce polskiej około 1900 roku, [w:] Mowa i moc obrazów. Prace dedykowane profesor Marii Poprzedqkiej, Warszawa 2005, s. 301; M. Nawrocka-Teodorczyk, Katalog, [w:] Mela Muter. Malarstwo, red. M. A. Supruniuk, Katalog zbiorów Muzeum Uniwersyteckiego w Toruniu, t. 1, Toruń 2010, s. 56; Konserwację obrazu przeprowadzono od końca 1998 r. do końca 1990 roku w Warszawie; Dokumentacja konserwatorska obrazu Portret Leopolda Staffa, opr. kons. Aldona Romanowicz, XII 1990 r., maszynopis; własność prywatna rodziny Nawrockich, s. 6.

11 Budowa niniejszego obrazu została szczegółowo omówiona w artykule: K. A. Cybulska, Mela Muter's paintings on cardboard - preliminary analysis, [w:] Interdisciplinary research on the works of art, Toruń 2012, s. 239-253. 
tomogramach OCT jako czarny pasek. Zwłaszcza w obszarze sygnatury tworzy ona wyraźne zgrubienia (oznaczone jako 3a na il. 2d). Dzięki porównaniu tomogramów OCT z fotografia mikroskopowa przekroju próbki pobranej $\mathrm{w}$ innym miejscu (w partii brązu niedaleko sygnatury artystki, przy krawędzi obrazu) można z cała pewnością stwierdzić, że jest to warstwa przeklejenia, które lokalnie układa się w grudki. Jest to przykład najbardziej typowego zastosowania techniki OCT w połączeniu z klasycznymi badaniami stratygraficznymi. Używamy informacji uzyskanych z przekrojów pobranych próbek (których liczba i lokalizacja jest oczywiście ograniczona względami etyki konserwatorskiej) jako klucza do interpretacji danych OCT, uzyskanych w sposób nieinwazyjny w wielu miejscach, w tym również takich, gdzie próbek z zasady się nie pobiera - jak na przykład z rejonu sygnatury.

Kolejnym zagadnieniem była analiza dwu sygnatur artystki, które budziły pewne wattpliwości. Sygnatura Muter na obrazie olejnym na płótnie pt. Gtowa kobiety (w skreconym warkoczu ponižej ucha) (il. 3a) wygląda na napisaną ołówkiem ${ }^{12}$. Za pomoca trójwymiarowego obrazowania OCT (szybka wysokorozdzielcza profilometria powierzchni) próbowano odpowiedzieć na pytanie, czy narzędzie pozostawiło odcisk w warstwie malarskiej, a tym samym czy sygnatura została naniesiona na względnie świeżo namalowany obraz. Dzięki prezentacji wyników w formie wysokorozdzielczej mapy elewacyjnej powierzchni warstwy malarskiej (Fig. 3c), udało się stwierdzić, że sygnatura nie została odciśnięta $\mathrm{w}$ farbie, została natomiast naniesiona na gotowy, wyschnięty obraz ${ }^{13}$.

Z kolei sygnatura MUTER na obrazie olejnym na płótnie pt. Kobieta bržemienna (il. 4a, b) robi wrażenie, jakby ostatnia litera napisana była farba o innym kolorze niż pozostałe. Wykonano skanowanie OCT dwóch liter:

12 Obraz został kupiony przez Bolesława Nawrockiego w Kolonii w 1974 r. Konserwację przeprowadziła Jadwiga Wardzyńska w Warszawie w 1982 r.; M. Nawrocka-Teodorczyk, Katalog, s. 76.

13 Widniejąca w lewym dolnym rogu sygnatura złożona została latem przez artystkę 1965 roku, w obecności dr Bolesława Nawrockiego, eksperta w dziedzinie prawa autorskiego, pracującego w tym okresie w Paryżu w UNESCO. To właśnie za rada dr Nawrockiego Mela Muter sygnowała w tym okresie wiele nie podpisanych dotąd swych prac malarskich; Prywatne Archiwum Rodziny Nawrockich. 
$U$ oraz $R$. Poprzez trójwymiarowe obrazowanie OCT, a następnie wizualizację wyników w formie chmury punktów uzyskanej w programie Amira, udało się stwierdzić, że struktura porównywanych liter o różnym składzie pigmentowym, w tym grubość warstwy malarskiej, w obrębie sygnatury jest bardzo podobna (il. 4c). Wskazane byłoby w tym przypadku wzbogacenie interpretacji o wyniki nieinwazyjnych badań spoiwa malarskiego w obrębie dwóch rodzajów liter. Należy w tym miejscu zauważyć, że chociaż autentyczność obrazu nie budzi wątpliwości (zwłaszcza w świetle jego znanej i zawiłej historii ${ }^{14}$ ), interesującym zagadnieniem jest autentyczność samej sygnatury.

Podjęto również próbę zastosowania tomografii optycznej do oceny pewnych aspektów dawnych nieudokumentowanych ingerencji konserwatorskich. Typowym problemem były nierówno założone wtórne werniksy, których obecność stwierdzono na obrazach: Glowa kobiety 2, Na plaży ${ }^{15}$, Dziewczynka na kržésle ${ }^{16}$ Pejzaż prowansalski z drzewami oliwkowymi.

W przypadku dwóch obrazów olejnych na sklejce: Driewczynka z warkoczykkami (il. 5a), Portret kobiety w czepku dążono do ustalenia, czy białawe bądź podbarwiane kity (woskowe?) założone sa poprawnie w rejonach ubytków. W przypadku obu obrazów dzięki analizie tomogramów OCT ustalono, że kity zachodzą na oryginalną warstwę malarską (il. 5c).

Ostatnim nietypowym zastosowaniem tomografii optycznej w badaniach grupy obrazów z kolekcji autorstwa Meli Muter była próba oceny stanu zachowania i bezpieczeństwa obrazów wykonanych w technice paste-

14 Około 1950 roku Mela Muter namalowała Bremienna kobiete (Akt kobiecy) na odwrociu przeciętego na dwie części wielkoformatowego obrazu na płótnie pt. Smutny kraj, z 1906 r.; Zob. J. Olszewska-Świetlik, K. A. Cybulska, Konserwator wobec autorskich żmian; M. Nawrocka-Teodorczyk, Katalog, s. 102.

15 Jest to jeden z obrazów odnalezionych w bardzo złym stanie przez Bolesława Nawrockiego w składzie węgla na przedmieściach Paryża. Konserwacje przeprowadziła Dorota Wardzyńska-Oraczewska, w Warszawie w 1900 r.; M. Nawrocka-Teodorczyk, Katalog, s. 174.

16 Portret dziewczynki siedzącej na krześle został przez samą Muter zamalowany na biało, a na jego odwrocie artystka namalowała ok. 1960 r. Portret młodej kobiety z kolcaykami w usqach. W 1980 r. obrazy rozdzielono w Turynie we Włoszech. W lipcu 1988 r. ówczesny właściciel obrazów Oskar Ghez podarował portret dziewczynki Bolesławowi Nawrockiemu. Dzięki pokryciu malowidła warstwą białego gruntu, lico malowidła stosunkowo dobrze się zachowało; M. Nawrocka-Teodorczyk, Katalog, s. 102. 
lu bez wyjmowania ich z opraw. Jako że kolekcja stanowi depozyt, pastele nie były rutynowo oprawiane w nowe oprawy w Muzeum Uniwersyteckim. Ponieważ niektóre oprawy nie są zaopatrzone w passe-partout, powstała wątpliwość, czy posiadaja one wystarczającej grubości tekturki dystansujące i czy wrażliwa warstwa barwna nie dotyka bezpośrednio do szkła. Wiadomym jest, że w takich sytuacjach istnieje niebezpieczeństwo przeniesienia pigmentu na szkło, co oznacza uszkodzenie obrazu. Należy dodać, że sam fakt istnienia tekturki dystansującej czy passe-partout w oprawie nie jest jeszcze wystarczającym warunkiem bezpieczeństwa obiektu, ponieważ deformacje (wybrzuszenia) papierowego podłoża obrazu moga powodować, że warstwa malarska będzie dotykać szkła pomimo „dystansu”. Technika OCT nadaje się dobrze do obrazowania obiektów przez szkło ${ }^{17}$. Zbadano dwa obrazy pastelowe. W przypadku obrazu pt. Kalwaria Bretońska - Pieta zaopatrzonego w passe-partout stwierdzono, że warstwa malarska nie dotyka szkła w miejscu wyraźnie widocznego wybrzuszenia papieru. Odległość warstwy malarskiej od szkła wahała się od 0,8 do 1,9 mm. Z kolei obraz pastelowy pt. Ścieżka (il. 6a) nie był oprawiony w passe-partout i trudno było stwierdzić, czy posiada jakiekolwiek zabezpieczenie dystansujące. Wykonano badania OCT w kilku miejscach (z których przykładowe dwa wyniki prezentuje il. 6b, c). Widoczna na tomogramach żółta linia to spodnia powierzchnia szklanej szyby, kolorem niebieskim zakodowana jest powierzchnia warstwy malarskiej. Po analizie tomogramów okazało się, że pomimo braku tekturki dystansującej wzdłuż górnej poziomej krawędzi ramy, warstwa malarska pastelu nie dotyka szkła. Było to spowodowane deformacja podobrazia - cofnięciem powierzchni papieru względem szkła. Odległość powierzchni obrazu od szkła wahała się w tym przypadku od $60 \mu \mathrm{m}$ do $1 \mathrm{~mm}$.

17 Zasadę badania obrazów przez szkło za pomocą OCT opisano w pracach: M. Iwanicka, L. Tymińska-Widmer, B. J. Rouba, E. A. Kwiatkowska, M. Sylwestrzak, P. Targowski Through-glass structural examination of Hinterglasmalerei by Optical Coherence Tomography, [w:] Proceedings of the international conference LACONA VIII - Lasers in the Conservation of Artworks, Sibiu, Romania, September 17-21, 2007, red. R. Radvan, CRC Press, Taylor \& Francis Group, Londyn 2011, s. 209-214; M. Iwanicka, E. A. Kwiatkowska, M. Sylwestrzak, P. Targowski, Application of optical coherence tomography (OCT) for real time monitoring of consolidation of the paint layer in Hinterglasmalerei objects, Proc. SPIE 8084, DOI: 10.1117/12.890398, 80840G (2011). 


\section{Podsumowanie}

Koherencyjna tomografia optyczna (OCT) jest przydatnym narzędziem dla szybkich przeglądów konserwatorskich obiektów w kolekcjach muzealnych, pomagając zdefiniować problemy konserwatorskie i wskazując konkretne obiekty i miejsca do dalszych badań technikami analitycznymi.

Poprzez badania obrazów olejnych na rozmaitych podłożach pochodzących z kolekcji autorstwa Meli Muter udało się odpowiedzieć na pytania związane z budową techniczna, stanem zachowania i oceną efektów dawnych ingerencji autorskich i konserwatorskich. Połączenie informacji dotyczących budowy technicznej obrazu uzyskanych w sposób inwazyjny (przez pobieranie próbek) z danymi OCT powoduje, że ilość pobranych próbek może być zminimalizowana, a reprezentatywność uzyskiwanych wyników - większa. Tomografia optyczna dostarczyła dodatkowo wiedzy o budowie obrazów w miejscach, w których próbek się nie pobiera, tzn. w regionach sygnatur.

W przypadku pasteli możliwa była nieinwazyjna ocena bezpieczeństwa obiektu, poprzez pomiar odległości warstwy malarskiej od szkła. Możliwość dokonania tego rodzaju szybkiej oceny czy pastel wymaga rozmontowania i ponownej oprawy, może być przydatna zwłaszcza w przypadku dużej kolekcji („profilaktyczne” rozmontowywanie tego typu obiektów nie jest wskazane i może stanowić dla nich zagrożenie).

Za sukces należy uznać również fakt, że po raz pierwszy wykonano badania OCT tak dużej grupy obrazów in situ (w magazynach Muzeum Uniwersyteckiego w Toruniu).

\section{Podziękowania}

Prace nad zastosowaniem OCT do badań obiektów zabytkowych zostały przeprowadzone dzięki życzliwości i zrozumieniu ze strony dyrekcji Muzeum Uniwersyteckiego. Były finansowane z grantów badawczych MNiSW, a obecnie z projektu Charisma 7 PR UE, nr kontraktu 228330. Udział MI 
jest finansowany z programu Ventures realizowanego przez Fundację na rzecz Nauki Polskiej z funduszy UE - POIG.

\section{Summary}

\section{A non-invasive in situ examination of some objects from the collection of paintings and pastels by Mela Muter with Optical Coherence Tomography}

Optical Coherence Tomography is a non-contact and non-invasive technique of depth-resolved structural imaging within media scattering and/or absorbing nearinfrared light moderately. It utilizes a concept of low-coherence interferometry and thus light sources must be characterized by low temporal (to ensure high axial resolution) and high spatial (to ensure high sensitivity) coherence. The instrument used in this study has $4 \mu \mathrm{m}$ axial resolution and over $100 \mathrm{~dB}$ sensitivity. The modular construction based on fiber optics makes it fairly easy transportable and not requiring optical table mounting. The system's portability together with fast and straightforward data acquisition, makes OCT especially well suited for quick in situ evaluation of large museum collections of paintings.

A vast collection of seventy-one oil paintings and over one hundred drawings, watercolours, and graphics by Mela Muter (Maria Melania Mutermilch, 1876, Warsaw - 1967, Paris), gathered by Bolesław and Lina Nawrocki, is now on deposit to the Nicolaus Copernicus University Museum in Torun. Artistically active in the first half of the twentieth century within the École de Paris, Mela Muter became recognized mostly for the portraits depicting socialites of the time, as well as images of motherhood, children and old people.

The collection brings specific conservation problems. Since the works were mostly acquired from Muter herself, the attribution is not in question. Nevertheless, the majority of paintings bear signs of extent conservation treatment and/ or alterations performed by the artist in her late years, possibly including adding signatures.

The aim of the survey of the group of nine Mela Muter's paintings and two pastels was to define the conservation issues as well as to indicate the objects and areas for further examination with various analytical techniques. In result, the evaluation of secondary layers (varnishes and putties) was performed for seven paintings. The structure of the paint layer in the area of the signature was analyzed in three paintings. Finally, in case of two pastel paintings, the safety of pigment layer (its distance to the glass) was assessed. 


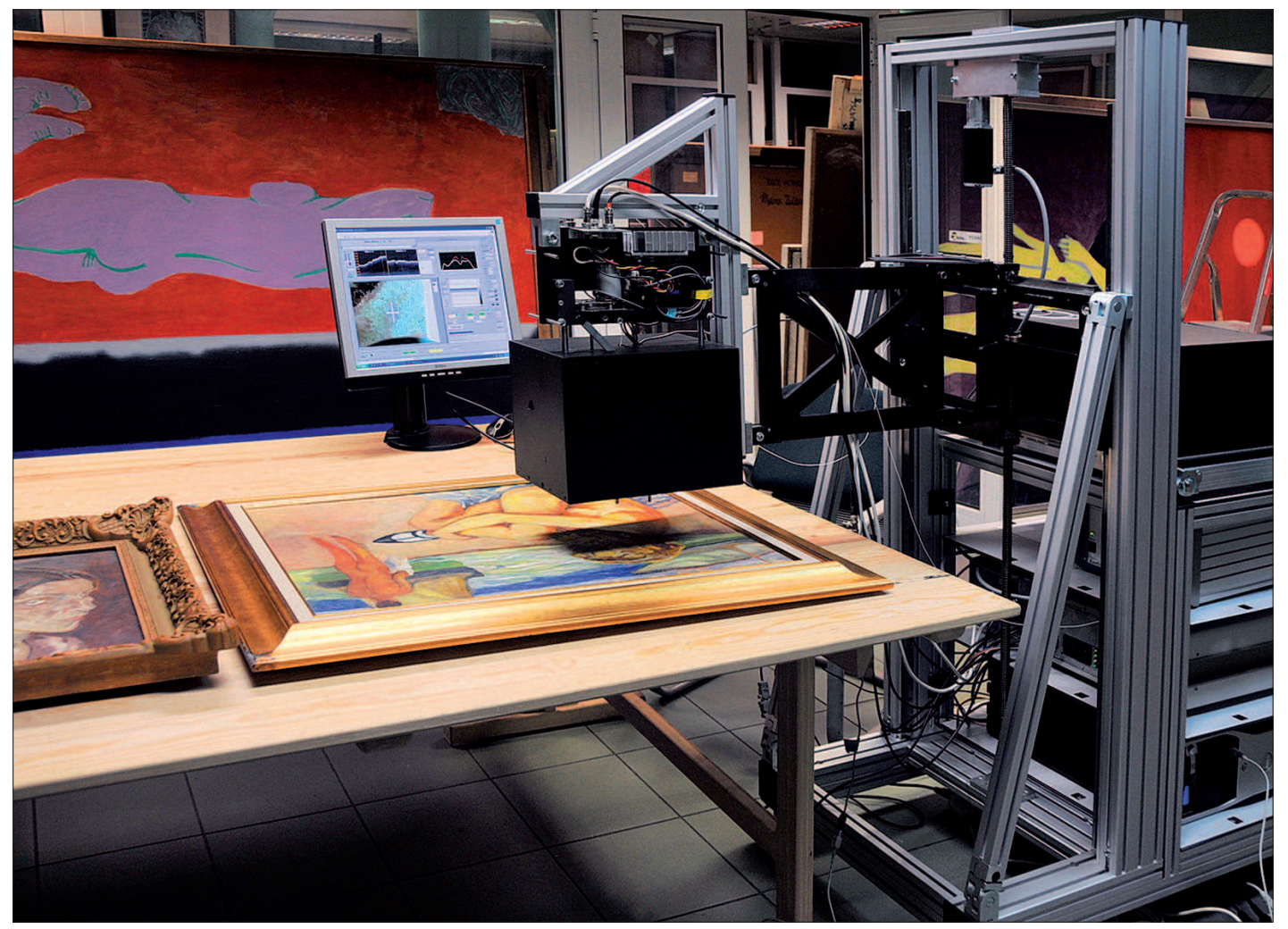

Il. 1. Mobilny tomograf OCT podczas badań obrazu Meli Muter w magazynach Muzeum Uniwersyteckiego w Toruniu (fot. M. Iwanicka) 
a

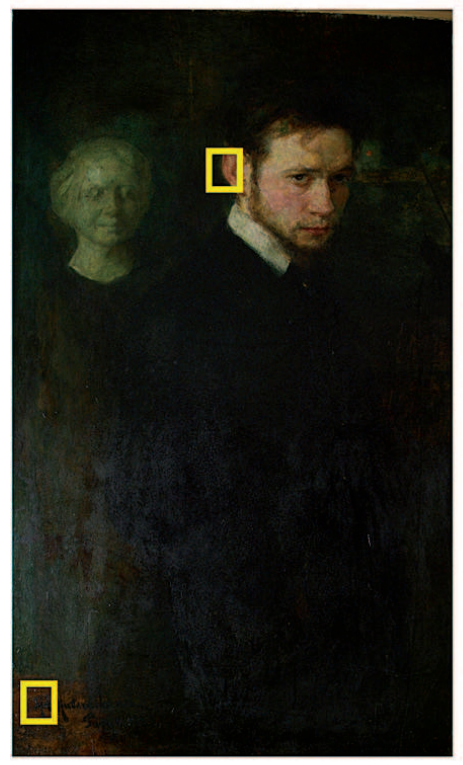

C
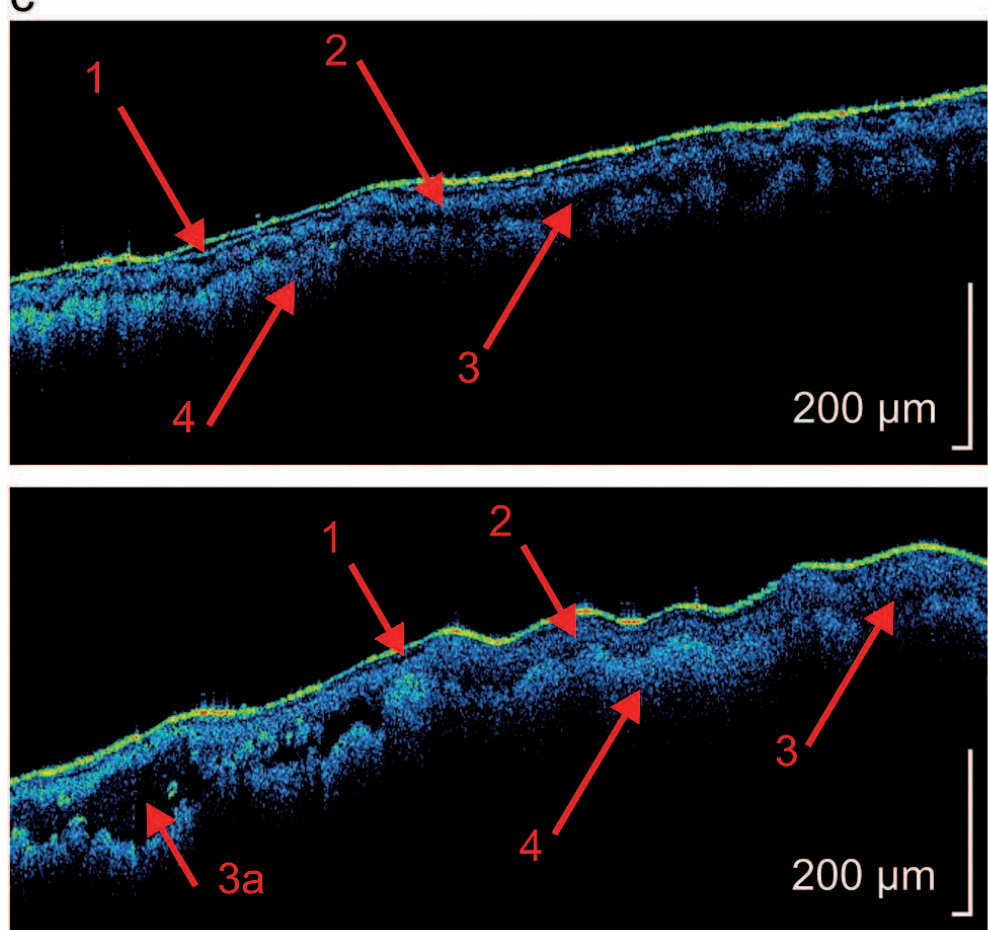

b

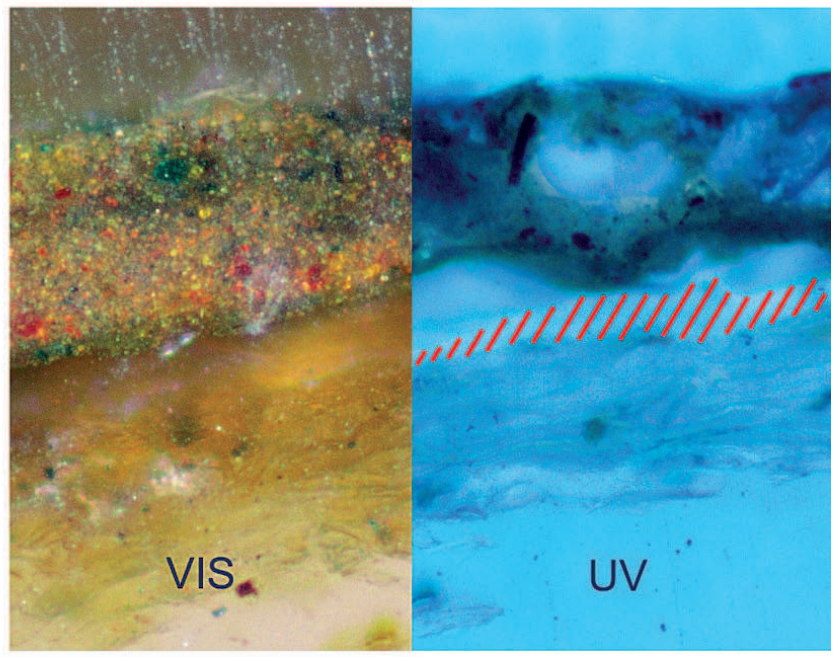

Il. 2. (a) Portret Leopolda Staffa (fot. A. Cupa) z zaznaczonymi miejscami badania OCT; (b) fotografia mikroskopowa przekroju próbki pobranej z okolicy sygnatury z zaznaczoną kreskowaniem warstwa przeklejenia (fot. dr Z. Rozłucka); (c) tomogramy OCT z odpowiadającymi miejscom badania makrofotografiami (fot. K. A. Cybulska), rozpoznane warstwy: 1. werniks, 2. półprzejrzysta warstwa malarska, 3. warstwa przeklejenia tworząca lokalnie grudki (3a), 4. podobrazie tekturowe nieprzezierne dla promieniowania podczerwonego 
a

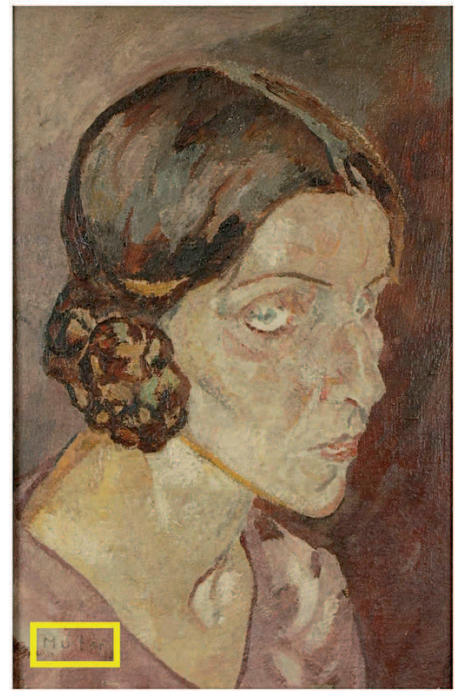

b

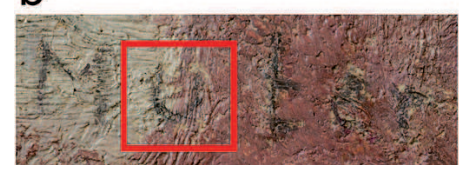

C

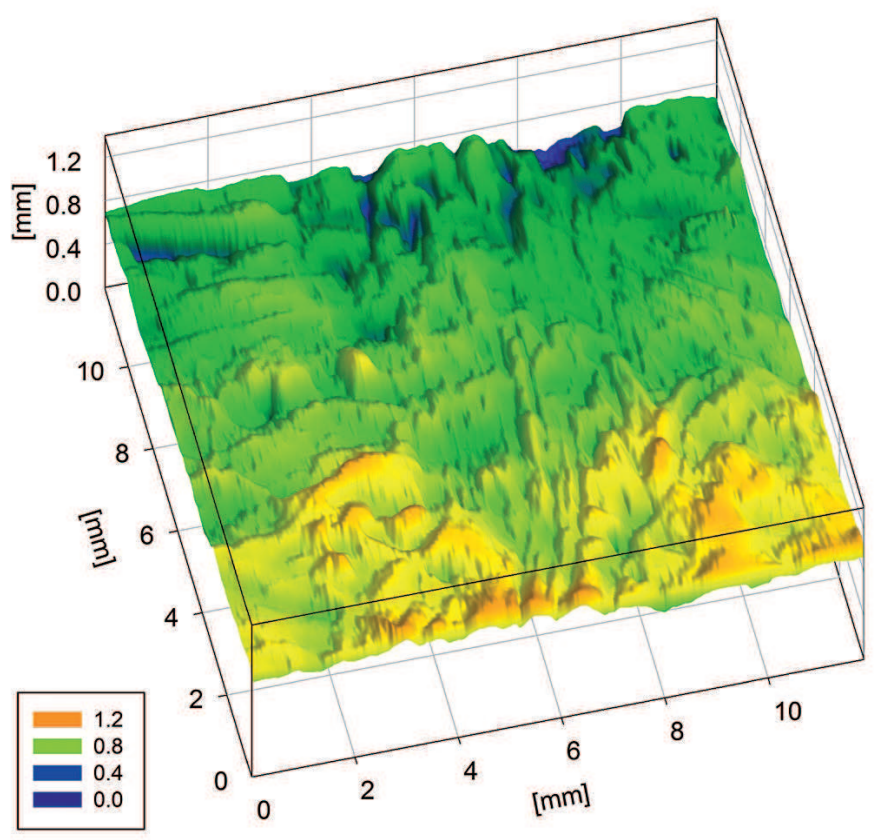

Il. 3. (a) Glowa kobiety (w skreconym warkoczu ponizej ucha), (fot. K. A. Cybulska); (b) fotografia sygnatury z zaznaczonym rejonem skanowania OCT, (fot. K. A. Cybulska); (c) mapa elewacyjna powierzchni uzyskana z danych OCT, widoczna ciagłość duktów pędzla w obszarze litery $u$, świadcząca o tym, że sygnatura nie jest odciśnięta w warstwie malarskiej. Kolor koduje wysokość nad płaszczyzną odniesienia 
a

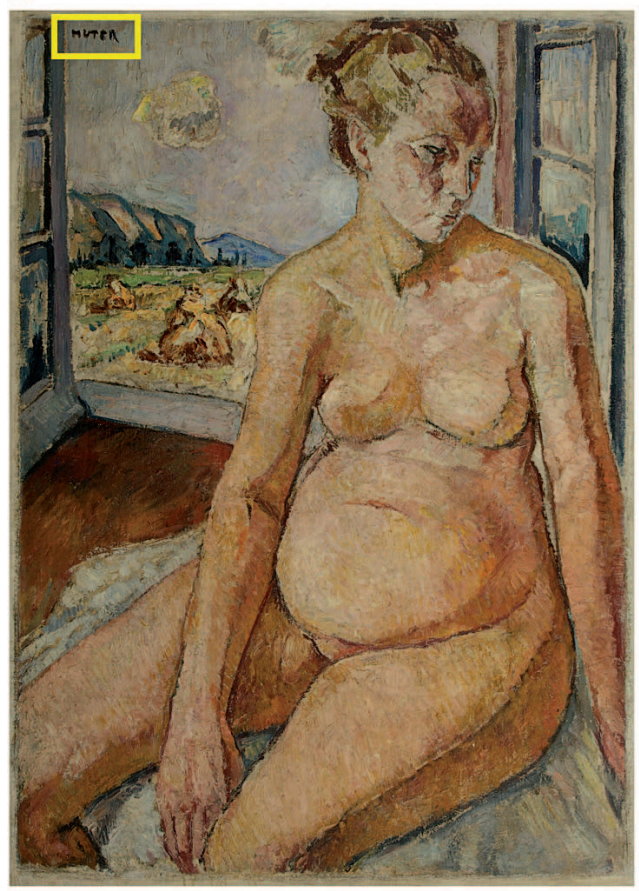

b

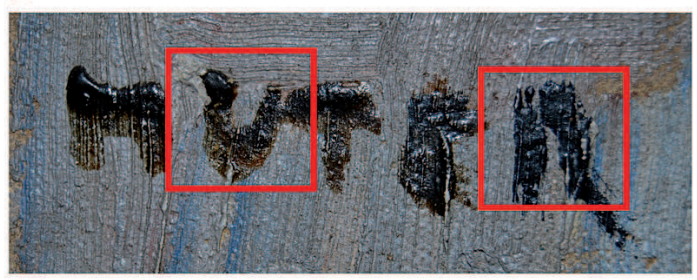

C

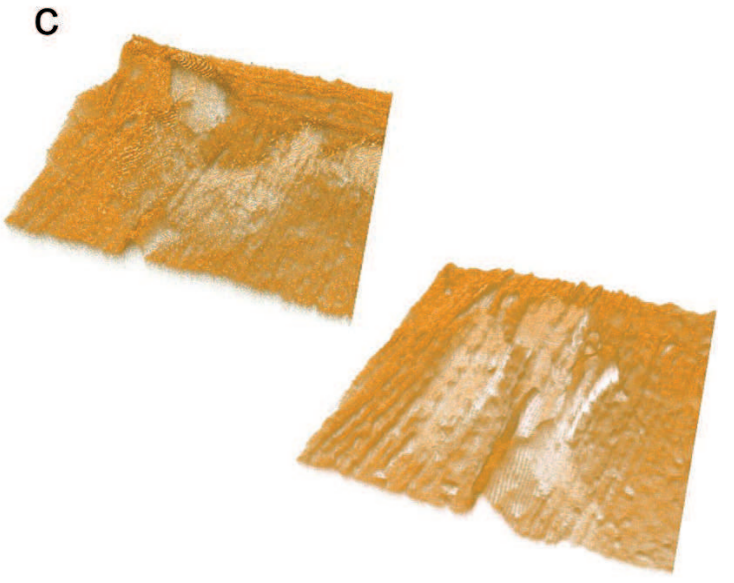

Il. 4. (a) Kobieta brzemienna (fot. P. Kurek); (b) fotografia sygnatury z zaznaczonymi rejonami skanowania OCT (fot. K. A. Cybulska); (c) wizualizacja struktury liter $U$ oraz $R$ uzyskana poprzez numeryczną obróbkę danych OCT 

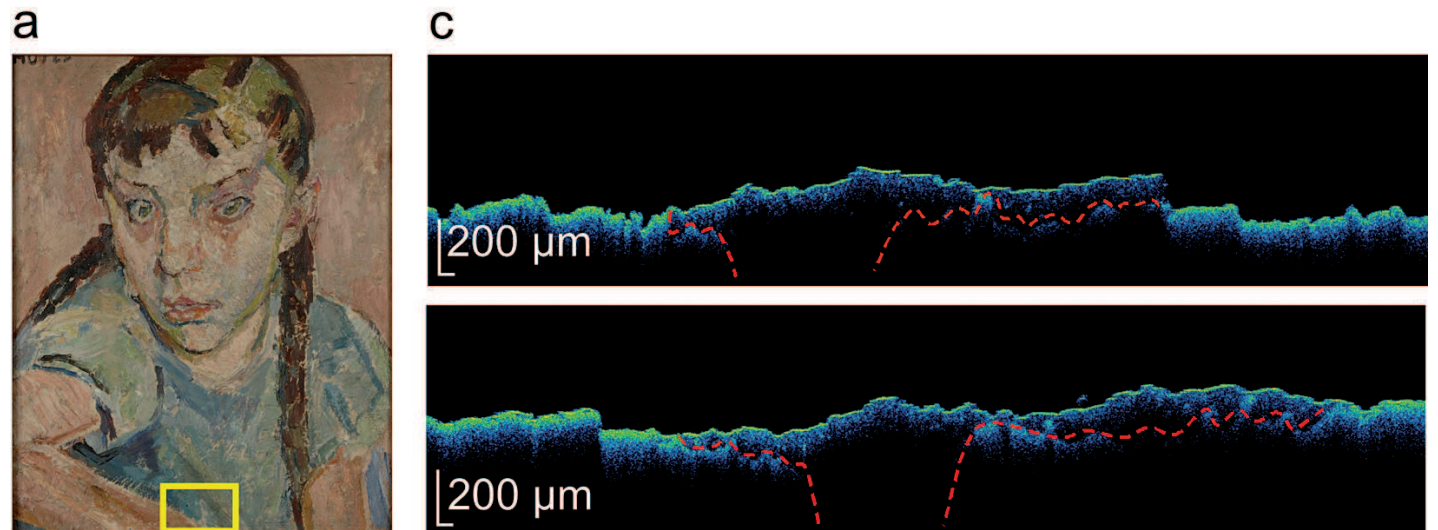

\section{b}
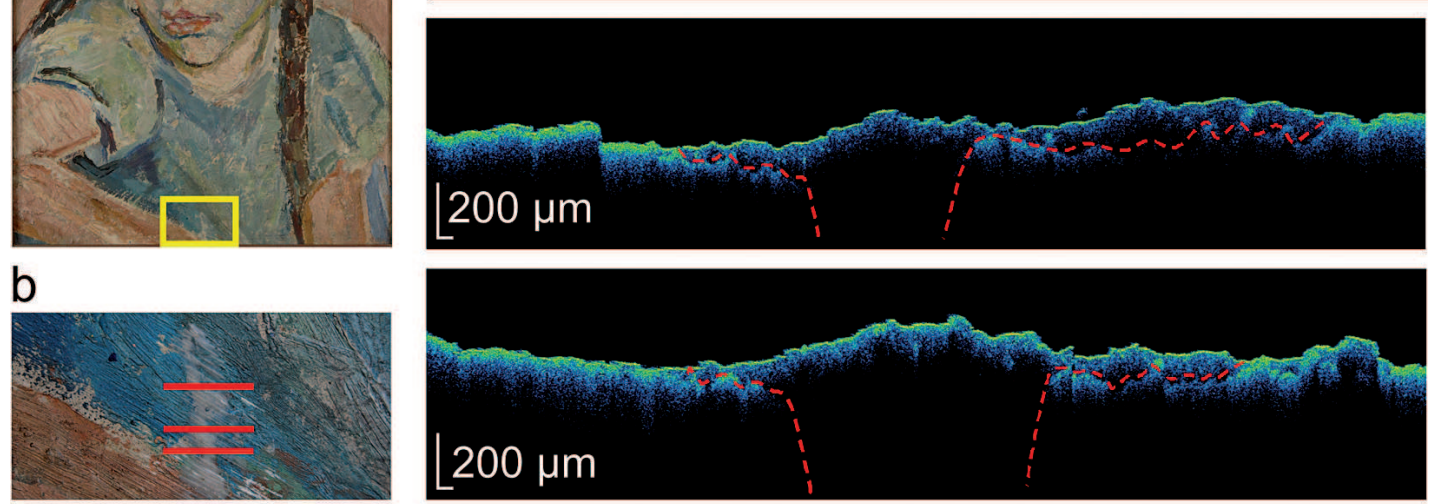

II. J. (a) Lzıewczynka z warkoczykeam (tot. K. A. Cybulska); (b) totogratia obszaru białawego kitu z zaznaczonymi miejscami skanowania OCT (fot. K. A. Cybulska); (c) tomogramy OCT uzyskane ze skanowania obszaru kitu, przerywaną linią zaznaczono zasięg kitu, który poza ubytkiem przysłania warstwę malarską

a

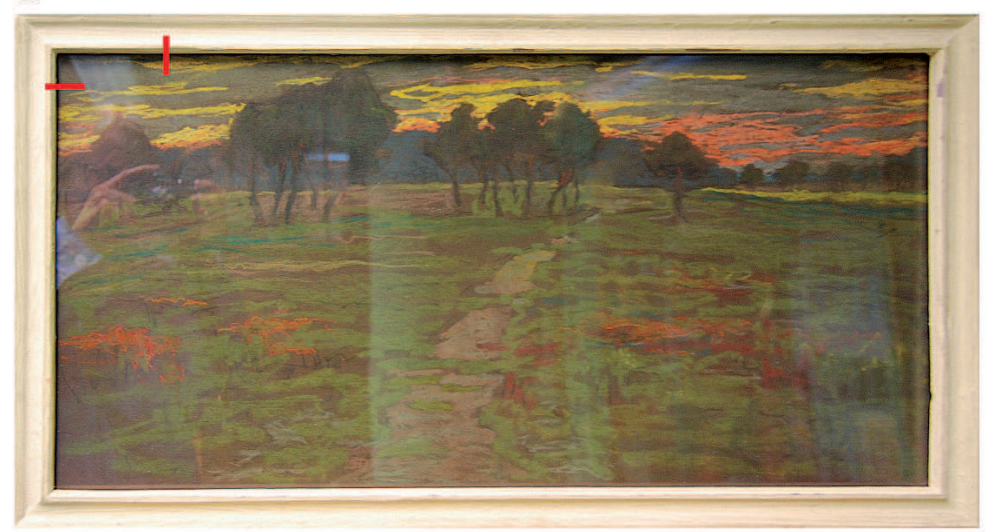

C

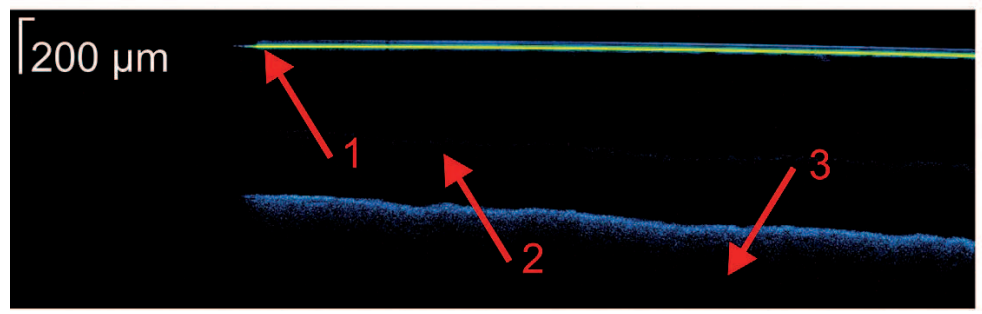

b

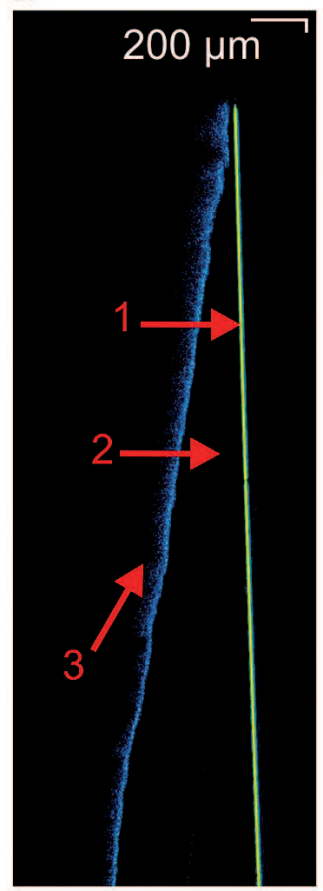

Il. 6. (a) Ściè̌ka, pastel za szkłem (fot. K. A. Cybulska); miejsca skanowania OCT zaznaczone na czerwono; (b, c) tomogramy OCT uzyskane w wyniku badania przez szkło, widoczne różnice w odległości warstwy malarskiej od szkła, 1. spodnia powierzchnia szkła, 2. powietrze, 3. pastel 